F. Reprod. Fert. (1969) 19, 423-432

\title{
IDENTIFICATION AND SUBCELLULAR LOCALIZATION OF THE ENZYMES EFFECTING PENETRATION OF THE ZONA PELLUCIDA BY RABBIT SPERMATOZOA
}

\author{
RICHARD STAMBAUGH AND JEAN BUCKLEY
}

\author{
Division of Reproductive Biology, Department of Obstetrics and Gynecology, \\ University of Pennsylvania School of Medicine, Philadelphia, Pa. 19104
}

(Received 2nd Fuly 1968)

\begin{abstract}
Summary. A sucrose density gradient centrifugation procedure for separating the subcellular components of washed and sonicated rabbit epididymal spermatozoa has been developed and applied to the subcellular localization of several sperm enzymes, including the acrosomal enzymes involved in penetration of the zona pellucida by the spermatozoon. These zona penetration enzymes were identified as hyaluronidase and a trypsin-like enzyme. They were extracted as a single complex, which sedimented in a sucrose gradient in the vicinity of proteins with molecular weights of 59,000 . The combined action of these two enzymes in the acrosomal extract produces a rapid and complete dissolution of the zona pellucida, which can be completely inhibited by soybean or lima bean trypsin inhibitors. Thus, penetration of the zona pellucida must be an enzymatic process involving mainly the trypsin-like enzyme of the acrosome. The subcellular localization of catalase, carbonic anhydrase, and the two kinetic forms of lactic dehydrogenase are also described to demonstrate the contrast in subcellular localization.
\end{abstract}

\section{INTRODUGTION}

Passage of the spermatozoon through the zona pellucida is a rapid process, judging from the infrequency with which eggs are recovered with the spermatozoon in the act of penetrating this mucoprotein barrier. Although a number of points of indirect evidence favour the participation of hydrolytic enzymes in sperm passage through the zona pellucida, little success has yet been obtained in attempts to extract such enzymes from mammalian spermatozoa. Since the sperm-head penetrates obliquely through the zona pellucida, the enzymes which effect the dissolution of the zona must be localized in the acrosomal cap covering the head of the spermatozoon. Srivastava, Adams \& Hartree $(1965 \mathrm{a}, \mathrm{b})$ have shown that lipoglycoprotein preparations from rabbit sperm acrosomes have a denuding effect and may cause dissolution of the zona pellucida. The following studies describe the detection and identification of the enzymes effecting penetration of the zona pellucida which were extracted from rabbit sperm acrosomes and were isolated by sucrose density gradient centri- 
fugation. The subcellular distribution of several other enzymes is also described to demonstrate the contrast in subcellular localization.

\section{MATERIALS AND METHODS}

\section{Protein determinations}

Protein concentrations were determined by the method of Lowry, Rosebrough, Farr \& Randall (1951).

\section{Enzyme assays}

Since the rabbit sperm lactic dehydrogenase (LDH) ' $\mathrm{X}$ ' sub-unit has the same kinetic properties as the ' $H$ ' sub-unit (Stambaugh \& Post, 1967), the ' $M$ ' kinetic type and total ' $\mathrm{H}$ ' + ' $\mathrm{X}$ ' kinetic type of $\mathrm{LDH}$ activity were determined using the spectrophotometric assay method described by Stambaugh \& Post (1966). Hyaluronidase was assayed by the turbidimetric method of Tolksdorf, McCready, McCullogh \& Sichwenk (1949). Hydrolytic activity on denatured haemoglobin was measured by the procedure of Anson (1938) at $\mathrm{pH}$ 7.4. Catalase activity was measured spectrophotometrically by the method of Beers \& Sizer (1952). Carbonic anhydrase was measured by the electrometric method of Wilbur \& Anderson (1948). Ribonuclease was measured by the spectrophotometric procedure of Roth (1959). Alkaline and acid phosphatase were measured by their rate of hydrolysis of 0 -carboxyphenylphosphate by the procedures of Brandenberger \& Hanson (1953). $\beta$-Glucuronidase was assayed using phenolphthalein glucuronide as a substrate by the method of Fishman, Springer \& Brunetti (1948). $\alpha$-Amylase was measured by the method of Bernfeld (1951). Lysozyme was determined by the rate of lysis of Micrococcus lysodeikticus by the method of Shugar (1952). Leucine aminopeptidase activity was measured by the procedure of Mitz \& Schlueter (1958). Hydrolytic activity for $p$-toluenesulphonyl-L-arginine methyl ester (TAME) was measured spectrophotometrically by the procedure of Hummel (1959), and hydrolytic activity for benzoyl-L-arginine ethyl ester (BAEE) was measured spectrophotometrically by the procedure of Bergmeyer (1963).

\section{Whole sperm extract}

Epididymal spermatozoa were flushed from the caudal end of the epididymides of mature New Zealand White rabbits with $0.9 \%$ sodium chloride, and collected by centrifugation at $600 \mathrm{~g}$ for $15 \mathrm{~min}$ at $5^{\circ} \mathrm{C}$. The sperm pellet was washed twice by resuspension in 10 vols of cold $0.9 \%$ sodium chloride and centrifugation at $600 \mathrm{~g}$. The final washed sperm pellet was dispersed in 4 vol. of distilled water at $5^{\circ} \mathrm{G}$, and sonicated with a Branson model LS 75 sonifier at $2 \mathrm{~A}$ in an ice-bath until no intact midpieces or tails could be seen under the microscope. It is almost impossible to disrupt the dense sperm nuclei completely by this procedure, but most of the acrosomes are disrupted by the sonication.

\section{Sperm fractionation procedure}

Epididymal spermatozoa were collected and washed as described above. The final washed sperm pellet, however, was dispersed in 4 vol. of $0.9 \%$ sodium chloride instead of distilled water, and sonication was carried out for $1 \mathrm{~min}$ at 
$1 \mathrm{~A}$ in an ice-bath. The suspension in $0.5-\mathrm{ml}$ aliquots was layered on $10.35-\mathrm{ml}$ linear sucrose gradients in $1 \times 3 \frac{1}{2}$-in. centrifuge tubes containing $65 \%$ sucrose at the bottom, and $5 \%$ sucrose at the top of the tube in $0.05 \mathrm{M}$-tris buffer, $\mathrm{pH} 7.5$. These tubes were centrifuged at $600 \mathrm{~g}$ for $20 \mathrm{~min}$ at $5^{\circ} \mathrm{C}$. At the end of this time, the bottoms of the tubes were punctured with a No. 19 gauge needle and 7-drop fractions were collected. Slides were made from a sample of each fraction, and the number of heads, midpieces or tails per field at 250 magnifications was recorded with a phase-contrast microscope. The remaining portion of each fraction was used for the enzyme assay.

In many experiments, the acrosomes were isolated from the pooled head fractions. This fractionation step was carried out by a modification of the method of Srivastava et al. (1965a, b) for isolating acrosomes from whole spermatozoa directly. By this procedure, the pooled head fractions were centrifuged and the pellet of heads treated with $0.05 \%$ Hyamine (a commercial detergent) in $0.9 \%$ sodium chloride for $45 \mathrm{~min}$ at $37^{\circ} \mathrm{C}$. At the end of this treatment the nuclei were removed by centrifugation, while the less dense acrosomes remained in the supernatant solution. Addition of an equal volume of absolute ethanol at $5^{\circ} \mathrm{C}$ precipitated the acrosomes, which were collected by centrifugation. The acrosomal pellet was suspended in distilled water and dialysed against distilled water, while stirring at $5^{\circ} \mathrm{C}$ to remove the ethanol. The final acrosomal suspension, contained within the dialysis tubing, was then sonicated at $2 \mathrm{~A}$ for $6 \mathrm{~min}$ at $5^{\circ} \mathrm{C}$ to complete the disruption of the acrosomes. This solution was used for enzyme assays and for the dissolution of the zona pellucida of denuded ova.

\section{Test for zona pellucida dissolution activity}

Mature New Zealand White female rabbits were injected with 100 i.u. of human chorionic gonadotrophin ( $\mathrm{HCG}$ ) and the ova were collected from the Fallopian tubes $13 \frac{1}{2} \mathrm{hr}$ later by lavage with Eagle's medium. The cumulus oophorus was dispersed in 1-ml embryological watch glasses by exposing the ova to 100 units of hyaluronidase in $1.0 \mathrm{ml}$ of Eagle's medium. These partially denuded ova were transferred to $1.0 \mathrm{ml}$ of Eagle's medium containing $80 \mathrm{~m}$ equiv. $/ 1$ of added bicarbonate ion for a $1-\mathrm{hr}$ incubation at $37.5^{\circ} \mathrm{C}$, which disperses the corona cells (Stambaugh, Noriega \& Mastroianni, 1969). At the end of this time the completely denuded ova were transferred to the medium which was to be tested for enzyme activity. The progress of zona dissolution was followed at $37.5^{\circ} \mathrm{C}$ under an air-curtain incubator on a slide with a coverslip sealed with Vaseline.

\section{Molecular weight determinations}

The molecular weights of hyaluronidase and trypsin were estimated using sucrose gradient centrifugation by the procedure of Martin \& Ames (1961). Catalase, rabbit muscle $\mathrm{LDH}$, and cytochrome $\mathrm{C}$ were used as reference molecular weights.

\section{RESULTS}

\section{Enzyme content of whole epididymal spermatozoa}

In order to determine which enzymes were extractable from whole epididymal spermatozoa, the washed epididymal spermatozoa were subjected to prolonged 
sonication as described under Materials and Methods. The degradative enzymes capable of dissolving the mucoprotein of the zona pellucida were of primary interest in this study. Table 1 lists the enzymes, which were assayed in this whole epididymal sperm extract. As would be expected, a high level of hyaluronidase activity was found in this extract, which would be capable of hydrolysing the mucopolysaccharide component of the zona. Among the different substrates tested for proteolytic activity, significant activity was found with denatured haemoglobin, TAME and BAEE, but no activity was found with elastin, L-leucinamide, or hippuryl-L-phenylalanine. This substratespecificity is characteristic of the trypsin type of proteolytic activity. Interestingly, a considerable amount of catalase was found in the extract, which is

TABLE 1

ENZYMIC ACTIVITY OF WHOLE EPIDIDYMAL SPERM EXTRACT

\begin{tabular}{l|l|cl}
\hline \multicolumn{1}{c|}{ Enzyme assay } & \multicolumn{1}{c}{ Substrate } & \multicolumn{2}{c}{ Enzymic activity/mg protein } \\
\hline Hyaluronidase & hyaluronic acid & $16 \cdot 4$ Tolksdorf units \\
Proteolytic & denatured Hb & $38 \cdot 2$ Anson units \\
& elastin & 0 & \\
& TAME & 76 & milliunits* \\
& BAEE & 486 & milliunits* \\
& L-leucinamide & 0 & \\
Catalase & hippuryl-L-phenylalanine & 0 & \\
Carbonic anhydrase & hydrogen peroxide & $5 \cdot 83$ Beers \& Sizer units \\
LDH-M sub-unit & CO2 & 99 Wilbur \& Anderson units \\
LDH-H+X sub-unit & L-lactate & $38 \cdot 4$ milliunits* \\
Ribonuclease & yeactate RNA & $08 \cdot 0$ milliunits* \\
Alk. phosphatase & o-carboxy phenylphosphate & 0 & \\
Acid phosphatase & o-carboxy phenylphosphate & 0 & \\
B-Glucuronidase & phenolphthalein & 0 & \\
$\alpha$-Amylase & starch & 0 & \\
Lysozyme & Micrococcus lysodeikticus & 0 & \\
& & & \\
\hline
\end{tabular}

* International milliunits.

almost absent from the spermatozoa of many species. It is also noteworthy that ribonuclease and phosphatase, which are characteristic enzymes of lysozomes, are absent from rabbit spermatozoa. Therefore, the acrosomes of spermatozoa cannot be regarded as analogous to the lysozomes found in phagocytes.

\section{Characterization of the proteolytic activity}

Since this hydrolytic activity of BAEE, denatured haemoglobin and TAME is characteristic of the trypsin type of substrate specificity, the sperm enzyme was compared with crystalline trypsin by other criteria. Using BAEE as the substrate, a $\mathrm{pH}$ optimum of $8 \cdot 2$ was found for the sperm enzyme, identical to that for crystalline trypsin (Table 2).

Trypsin is unique among the proteolytic enzymes in that there are a large number of naturally occurring specific inhibitors of its enzymic activity. One of these is a protein extractable from soybeans with a molecular weight of 20,000 (Steiner, 1954). When this purified inhibitor was incubated with the sperm extract and BAEE, the trypsin-like enzyme was markedly inhibited, an action almost identical to that on crystalline bovine pancreatic trypsin. As shown in 
Table 3, soybean trypsin inhibitor in a concentration of $10 \mu \mathrm{g} / \mathrm{ml}$ depressed the enzymatic activity of both crystalline trypsin and the sperm enzyme to 10 to

TABLE 2

PH OPTIMA FOR BAEE HYDROLXSIS

\begin{tabular}{c|c|c}
\hline \multirow{2}{*}{$p H$} & \multicolumn{2}{|c}{$\%$ Maximal activity } \\
\cline { 2 - 3 } & Sperm extract & Crystalline bovine trypsin \\
\hline $7 \cdot 0$ & 62 & 58 \\
$7 \cdot 5$ & 75 & 76 \\
$7 \cdot 8$ & 78 & 80 \\
$8 \cdot 0$ & 84 & 94 \\
$8 \cdot 2$ & 100 & 100 \\
$8 \cdot 5$ & 84 & 76 \\
$9 \cdot 0$ & 76 & 72 \\
\hline
\end{tabular}

TABLe 3

INHIBITION OF BAEE HYDROLYSIS BY SOYBEAN TRYPSIN INHIBITOR

\begin{tabular}{c|c|c|c}
\hline \multirow{2}{*}{$\begin{array}{c}\text { Concentration } \\
\text { of }\end{array}$} & \multicolumn{3}{|c|}{$\%$ Maximal activity } \\
\cline { 2 - 4 } $\begin{array}{c}\text { inhibitor } \\
(\mu \mathrm{g} / \mathrm{ml})\end{array}$ & $\begin{array}{c}\text { Sperm } \\
\text { extract }\end{array}$ & $\begin{array}{c}\text { Crystalline } \\
\text { bovine trypsin }\end{array}$ & $\begin{array}{c}\text { Crystalline } \\
\text { papain }\end{array}$ \\
\hline 0 & 100 & 100 & 100 \\
$3 \cdot 12$ & 28.2 & $39 \cdot 2$ & 93.3 \\
$15 \cdot 6$ & $12 \cdot 1$ & $8 \cdot 35$ & $80 \cdot 1$ \\
62.5 & $9 \cdot 32$ & $2 \cdot 50$ & 63.3 \\
156 & $7 \cdot 25$ & $2 \cdot 23$ & 55.9 \\
312 & 6.90 & 1.95 & 72.0 \\
\hline
\end{tabular}

TABLE 4

INHIBITION OF BAEE HYDROLYSIS BY LIMA BEAN TRYPSIN INHIBITOR

\begin{tabular}{c|c|c|c}
\hline \multirow{2}{*}{$\begin{array}{c}\text { Concentration } \\
\text { of } \\
\text { inhibitor } \\
(\mu g / m l)\end{array}$} & \multicolumn{3}{|c}{$\%$ Maximal activity } \\
\cline { 2 - 4 } & Sperm & $\begin{array}{c}\text { Crystalline } \\
\text { extract }\end{array}$ & $\begin{array}{c}\text { Crystalline trypsin } \\
\text { papain }\end{array}$ \\
\hline 0 & 100 & 100 & 100 \\
$3 \cdot 12$ & $86 \cdot 0$ & $61 \cdot 9$ & 108 \\
$15 \cdot 6$ & $37 \cdot 0$ & $44 \cdot 7$ & 123 \\
62.5 & $8 \cdot 66$ & $4 \cdot 76$ & 159 \\
156 & $4 \cdot 09$ & $2 \cdot 99$ & 203 \\
312 & $2 \cdot 99$ & $1 \cdot 79$ & - \\
\hline
\end{tabular}

$20 \%$ of the maximal rate with no inhibitor present. Papain, a plant enzyme also active on this substrate, was only slightly inhibited by these concentrations of soybean extract.

Another naturally occurring inhibitor for trypsin is a lima bean protein with a molecular weight of 9,000 to 15,000 (Frankel-Conrat, Bean, Ducay \& Olcott, 1952). Purified lima bean inhibitor in a concentration of $50 \mathrm{mg} / \mathrm{ml}$ also depressed 
the activity of both trypsin and the sperm enzyme to $10 \%$ of the maximal rate with no inhibitor present (Table 4). Surprisingly, crystalline papain displayed increased enzymatic activity in the presence of lima bean trypsin inhibitor.

Evidently, then, a fairly active proteolytic enzyme was being extracted, possibly capable of dissolving the protein component of the zona pellucida, and having many of the enzymic characteristics of pancreatic trypsin.

Subcellular localization of the sperm enzymes

In order to determine the subcellular localization of the enzymes effecting penetration of the zona pellucida, the sucrose density gradient fractionation procedure was applied. Plate 1 shows a sucrose gradient tube containing the resolved bands of heads, midpieces and tails, and Text-fig. 1(a) shows the distribution of these subcellular particles in a total of forty-five fractions

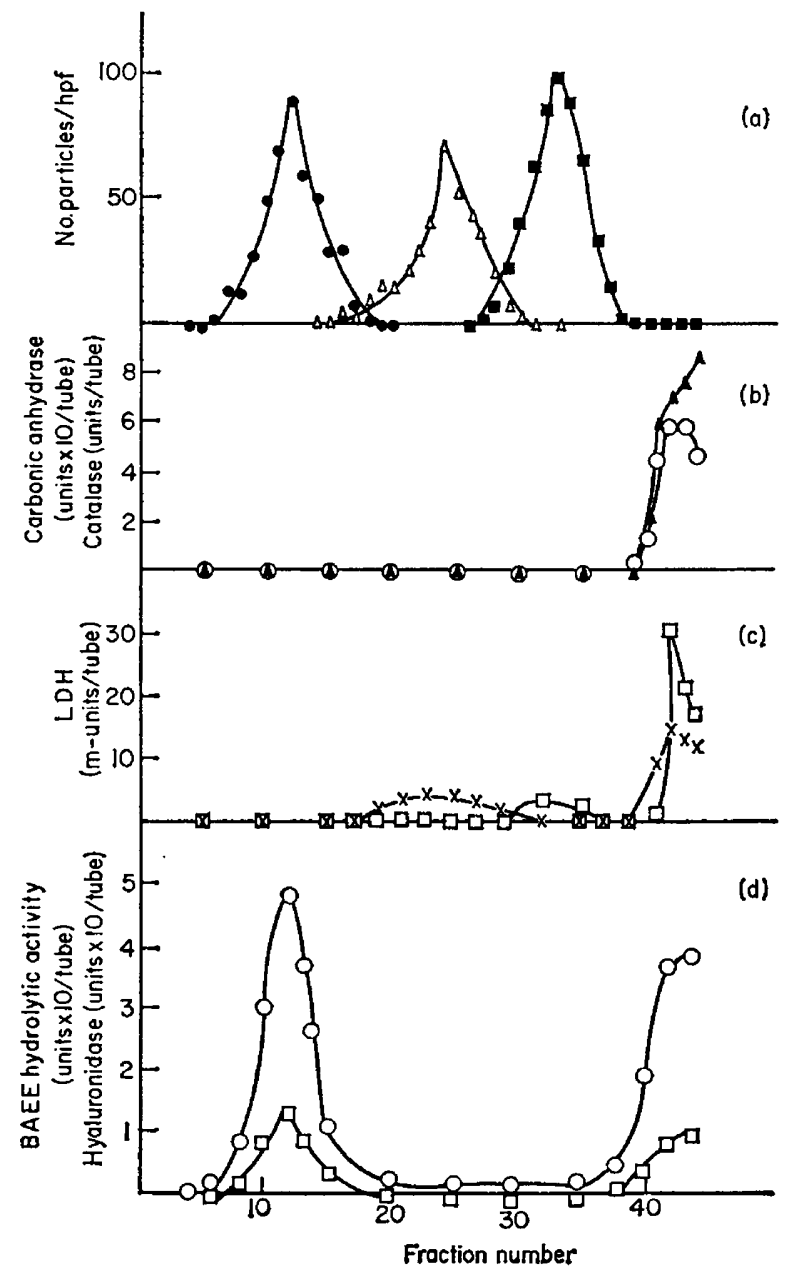

TEXT-FIG. 1. Analysis of fractions collected from the sucrose density gradient tube: (a) distribution of heads, midpieces and tails per high power field (hpf), (b) distribution of carbonic anhydrase $(\Lambda)$ and catalase $(O)$ activities, (c) distribution of $\mathrm{LDH}$ ' $M$ ' subunit $(\square)$ and ' $H$ ' + ' $X$ ' subunit $(x)$ activities, (d) distribution of hyaluronidase ( $O$ ) and BAEE hydrolytic $(\square)$ activities. 
PIATE 1

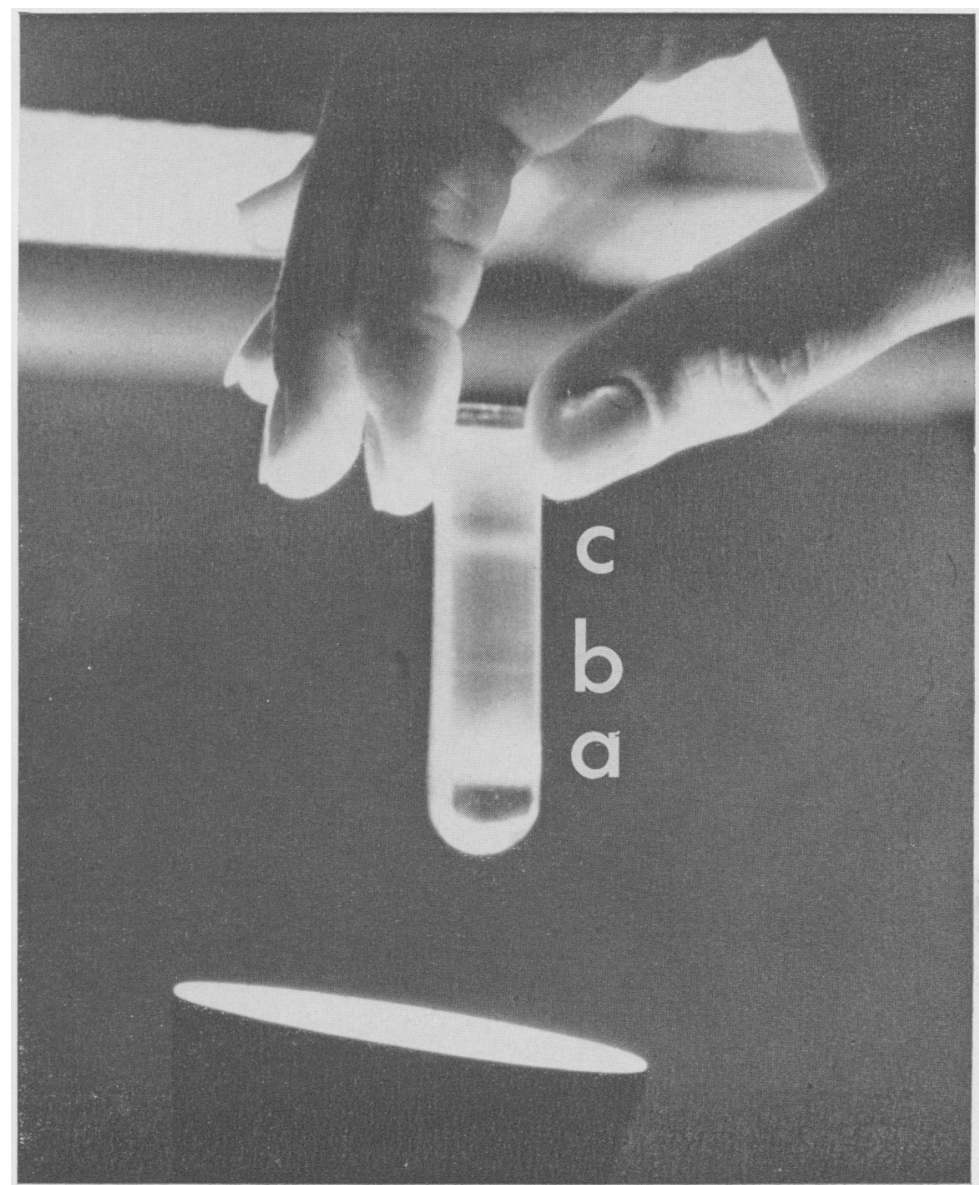

Sucrose density gradient tube containing the resolved bands of heads a), midpieces (b) and raits (c).

(Facing p. 428) 
PLATE 2

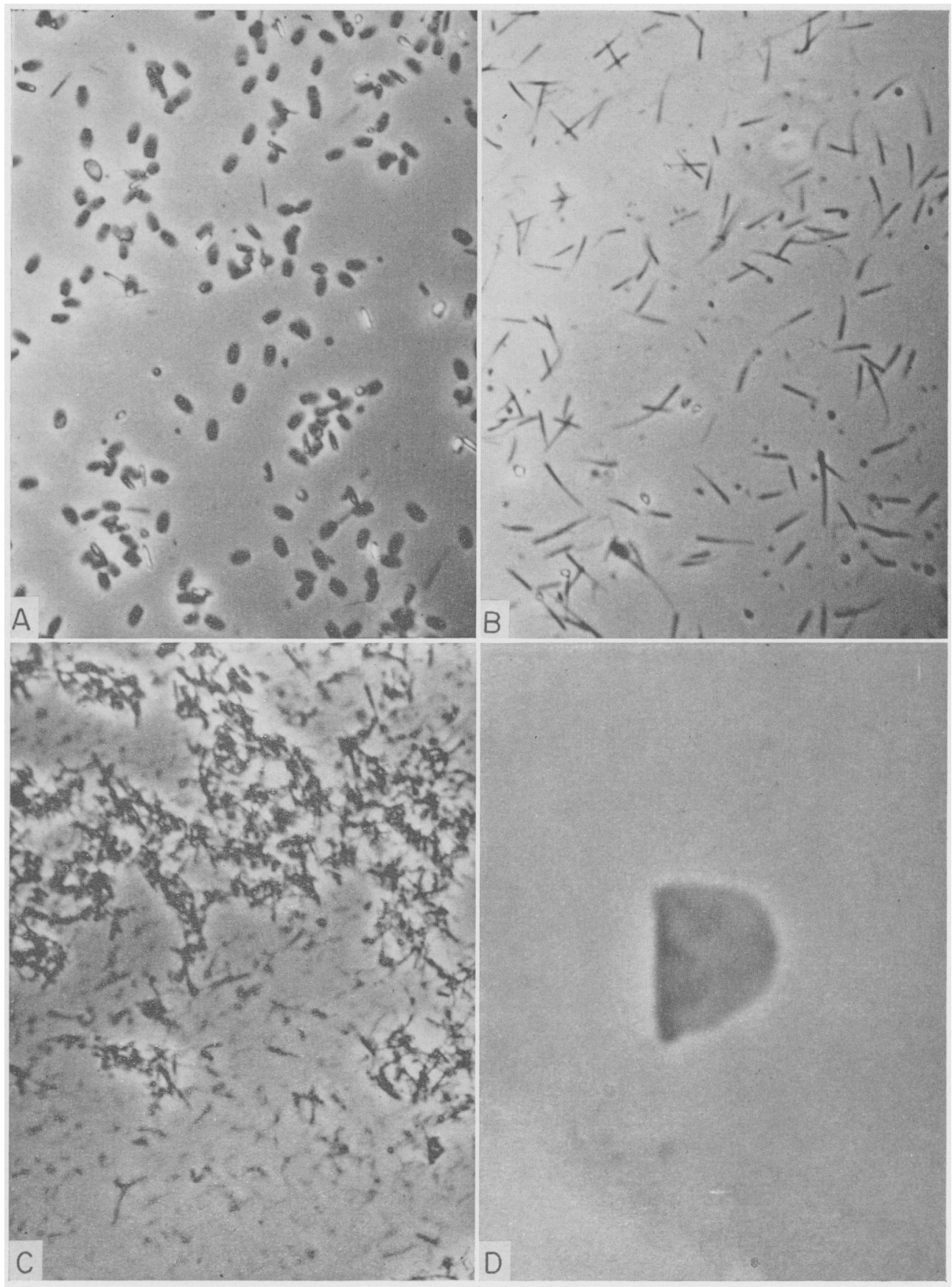

Phase-contrast photomicrographs of: (A) peak head fraction. $\times 100 ;$ (B) peak midpiece: fraction, $\times 100$; (C) peak tail fraction, $\times 100$; (1) acrosome remored from head with Hyaminte $\times 630$. 


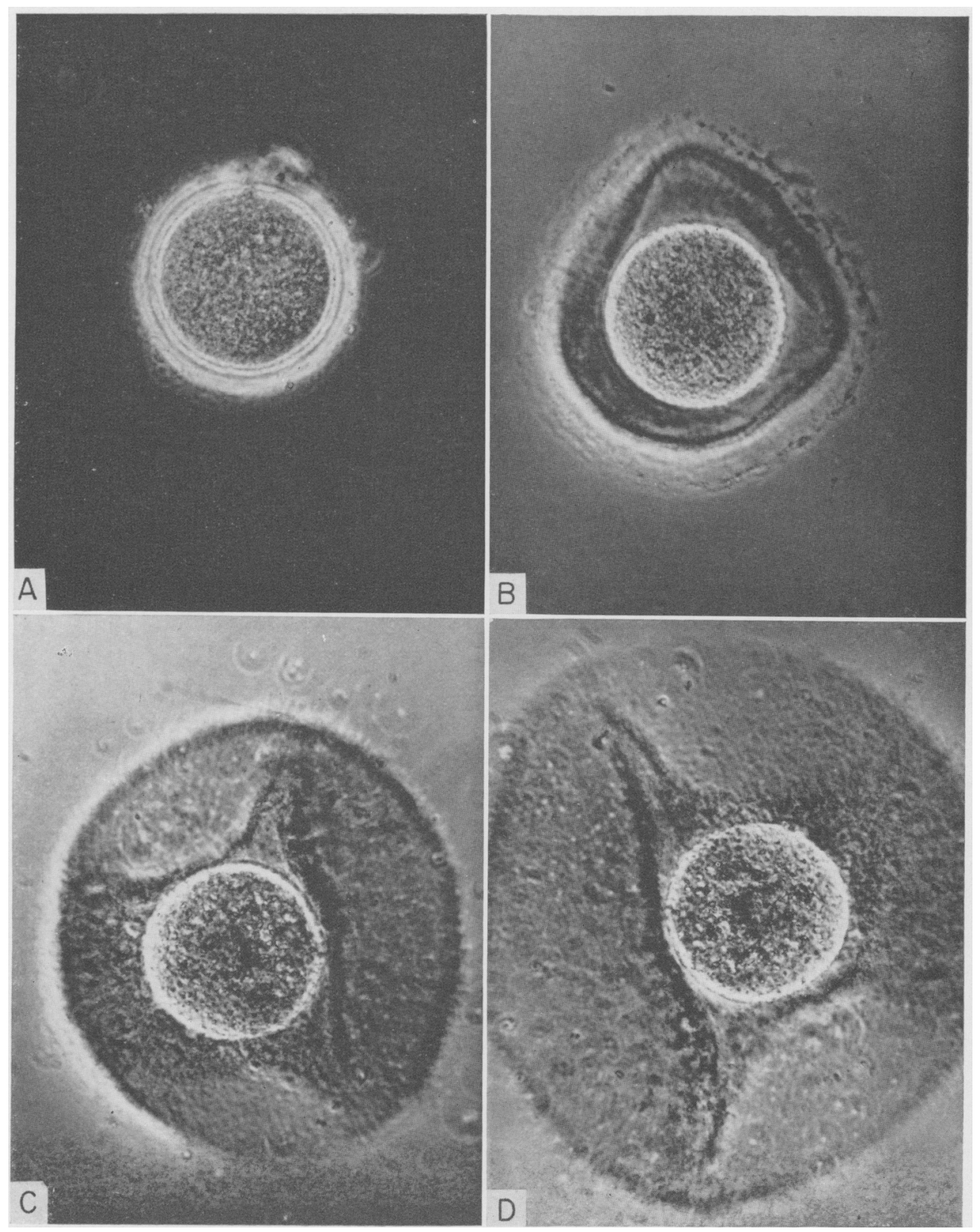

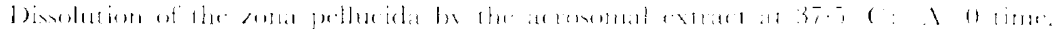

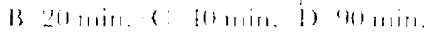


collected from the gradient tube. It can be estimated that the peak fraction of heads contains $5 \%$ (or less) midpieces, the peak midpiece fraction contains 1 to $3 \%$ heads and the peak tail fraction contains 1 to $3 \%$ of heads plus midpieces. These are reasonably pure fractions by any subcellular fractionation procedure, and the heads and midpieces displayed minimal damage from the sonication procedure. An occasional midpiece or head showed some visible damage, but the majority of acrosomes remained attached to the heads. The homogeneity of the head, midpiece and tail fractions is shown in Plate 2.

The subcellular distributions of the sperm enzymes are also shown in Textfig. 1. All of the carbonic anhydrase and catalase activity was found to be localized in the soluble portion of the cell, which remained at the top of the sucrose gradient (Text-fig. 1b), while the LDH activity was distributed among the midpiece, tail and soluble portions of the cell, with the largest amount occurring in the soluble portion (Text-fig. 1c). The midpieces contained almost exclusively the ' $\mathrm{X}$ ' + ' $\mathrm{H}$ ' kinetic type of $\mathrm{LDH}$ activity, the forms best suited for

TABLE 5

HYALURONIDASE AND BAEE HYDROLYTIC ACTIVITY IN EXTRACTS OF WHOLE SPERMATOZOA, SPERM HEADS, SPERM NUGLEI AND ACROSOMES

\begin{tabular}{|c|c|c|}
\hline Extract & $\begin{array}{c}\text { Hyaluronidase } \\
\left(\frac{\text { Tolksdorf units }}{\text { mg protein }}\right)\end{array}$ & $\begin{array}{c}B A E E \text { hydrolytic activity } \\
(m \text {-units*/mg protein })\end{array}$ \\
\hline $\begin{array}{l}\text { Whole sperm. } \\
\text { Sperm heads } \\
\text { (nuclei and acrosomes) }\end{array}$ & $\begin{array}{l}16 \cdot 4 \\
23 \cdot 7\end{array}$ & $\begin{array}{l}486 \\
761\end{array}$ \\
\hline $\begin{array}{l}\text { Nuclei } \\
\text { Acrosomes }\end{array}$ & $\begin{array}{l}11 \cdot 4 \\
48 \cdot 5\end{array}$ & $\begin{array}{r}282 \\
1460\end{array}$ \\
\hline
\end{tabular}

* International milliunits.

aerobic glycolysis, while the tails contained only the 'M' kinetic type of LDH activity, the form best suited for anaerobic glycolysis (Stambaugh \& Buckley, 1967). The hyaluronidase activity and BAEE hydrolytic activity were found in both the head and supernatant fractions and always in a relatively constant ratio to each other, indicating that they may exist as a single enzymatic particle. They were not found associated with the midpiece or tail fractions.

In order to ascertain the source of the hyaluronidase and trypsin-like activities, the pooled head fractions were fractionated further into nuclei and acrosomes. Removal of the acrosomes was accomplished with $0.05 \%$ Hyamine by a modification of the procedure of Srivastava et al. (1965b). An isolated acrosome, removed by this procedure, is shown in Pl. 2, Fig. D. The combination of the sucrose density gradient fractionation procedure with the use of Hyamine gave an uncontaminated extract of the acrosomes. Direct treatment of undisrupted and unfractionated spermatozoa with Hyamine, as described by Srivastava et al. (1965a, b), probably results in an acrosomal extract containing plasma membranes and soluble cytoplasmic enzymes in addition to the acrosomal extract. The specific activities of hyaluronidase and the trypsin-like enzyme in the acrosomal extract as compared with the specific activities in the sperm heads, sperm nuclei, and whole sperm extract are shown in Table 5. 
Significantly, the specific activities of both enzymes were highest in the acrosomal extract, indicating that they were contained within this structure. The small amounts of enzymatic activity remaining in the nuclear fraction was the result of incomplete removal of the acrosomes by the detergent, which was apparent from microscopic examination of this fraction.

\section{Molecular weight determinations}

An attempt was made to estimate the molecular weights of the acrosomal hyaluronidase and trypsin-like activity by sucrose density gradient centrifugation using the procedure of Martin \& Ames (1961). Surprisingly, the results (Text-fig. 2) indicated that the enzymes sediment as a single molecule corresponding to a molecular weight of 59,000 at the peak fraction. Hyaluronidase should have a molecular weight around 11,000 , while trypsin should have a molecular weight in the vicinity of 23,800 . Apparently we were extracting a complex molecule containing both enzymes, probably the lipoglycoprotein complex described by Srivastava et al. (1965a, b).

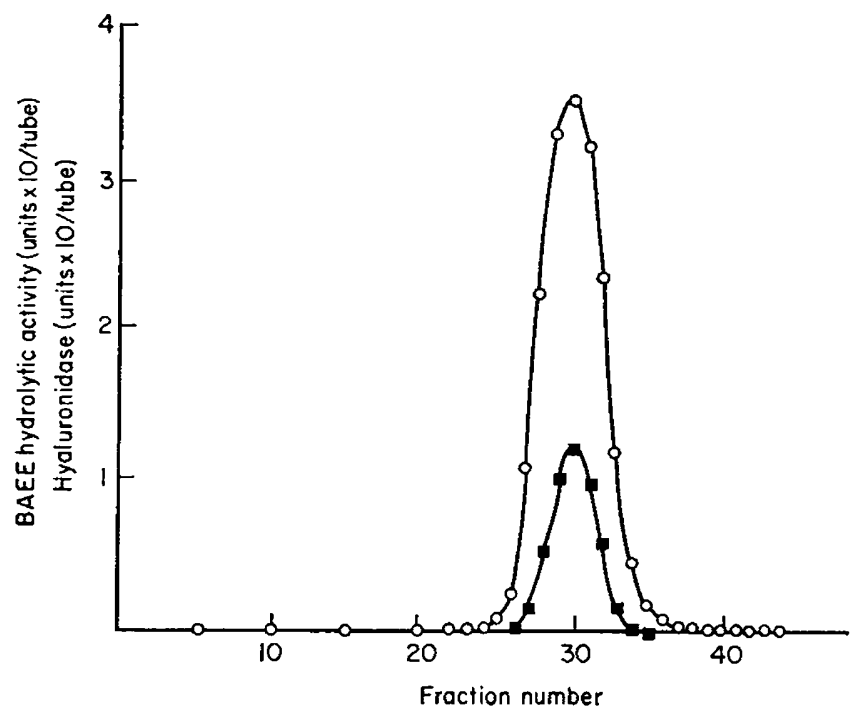

TExT-FIG. 2. Distribution of hyaluronidase (0) and BAEE hydrolytic ( $\boldsymbol{\sigma}$ ) activities in fractions from the sucrose density gradient tube used in the molecular weight determination.

\section{Dissolution of the zona pellucida by the acrosomal extract}

The acrosomal extract was made isotonic with sodium chloride. Denuded rabbit ova were transferred to this extract with a minimal quantity of Eagle's medium, and incubated at $37.5^{\circ} \mathrm{C}$ with an air-curtain incubator. The progress of zona dissolution in the unstained ovum is shown in Plate 3. Complete dissolution of the zona was obtained in $1 \frac{1}{2} \mathrm{hr}$ under these conditions. Separate light and dark regions of the zona pellucida are apparent during the dissolution process, supporting the observation by Dickmann (1965) that the zona pellucida of the rabbit consists of two distinct layers.

The process of dissolution can be completely inhibited by soybean trypsin inhibitor $(300 \mu \mathrm{g} / \mathrm{ml})$, or by the lima bean trypsin inhibitor $(300 \mu \mathrm{g} / \mathrm{ml})$, 
indicating that the trypsin component of this extract must be the more important enzyme in the dissolution process. This is supported by the authors' observation that crystalline hyaluronidase ( 375 units $/ \mathrm{ml}$ ) has no visible action on the zona pellucida even after a $24-\mathrm{hr}$ incubation at $37.5^{\circ} \mathrm{C}$, but crystalline trypsin ( 5500 units $/ \mathrm{ml}$ ) will completely dissolve the zona in $10 \mathrm{~min}$ at this temperature. These data indicate that penetration of the zona pellucida by the spermatozoon is an enzymic process involving mainly the trypsin-like enzyme of the acrosome. The hyaluronidase may supplement this process, or its physiological function may be to thin the cervical mucus or disperse the hyaluronic acid matrix of the cumulus oophorus of the undenuded ovum.

Recently, the authors have been able to demonstrate the prevention of fertilization in vitro by these soybean and lima bean trypsin inhibitors though sperm motility was not affected by the concentrations involved (Stambaugh, Brackett \& Buckley, unpublished). This provides additional evidence that the trypsin-like enzyme is, indeed, responsible for the ability of rabbit spermatozoa to penetrate the zona pellucida.

\section{DISGUSSION}

The subcellular fractionation procedure described here provides a simple and direct method for the subcellular localization of rabbit sperm enzymes. The ability of the bicarbonate ion to disperse the corona radiata of the rabbit ova has been shown by Mastroianni \& Ehteshamzadeh (1964) and Stambaugh, Noriega \& Mastroianni (1969), but, since carbonic anhydrase is not localized in the sperm head, it seems unlikely that this sperm enzyme is involved in bicarbonate ion synthesis to facilitate penetration of the corona radiata. The subcellular distribution of the two kinetic forms of $\mathrm{LDH}$ is also quite interesting. The midpieces, containing the mitochondria and site of aerobic glycolysis, contain exclusively the ' $\mathrm{X}$ ' and ' $\mathrm{H}$ ' subunits, the $\mathrm{LDH}$ forms best suited for aerobic glycolysis (Stambaugh \& Post, 1967). The tail fibres, on the other hand, contain the ' $M$ ' kinetic type of $\mathrm{LDH}$, which is the form best suited for anaerobic glycolysis (Stambaugh \& Post, 1967) and is the type found in striated muscle. All forms of LDH were found in the soluble cytoplasmic fraction of the spermatozoa.

By contrast, the subcellular fractionation procedure demonstrated that the hyaluronidase and trypsin-like activities were localized in the acrosomes of rabbit spermatozoa. The narrow slit made by the entry of the spermatozoon might be regarded as evidence against the action of released enzymes. These two enzymes might, however, remain firmly attached to the inner acrosomal membrane during the zona penetration process and carry out their degradation of the zona while still attached to this structure. It is probable that both enzymes are also components of the lipoglycoprotein complex described by Srivastava et al. $(1965 \mathrm{a}, \mathrm{b})$, since they sediment together in the ultracentrifuge as a single molecule. The rapid dissolution of the zona pellucida of the denuded rabbit ovum by the combined action of these enzymes is a reproducible phenomenon, and both enzymes have invariably been found in extracts of rabbit sperm acrosomes. The trypsin-like component of this enzyme complex is apparently the more important enzyme, since the dissolution process can be 
completely inhibited by soybean or lima bean trypsin inhibitors. However, since the zona is a mucoprotein, containing both mucopolysaccharide and protein components, the hyaluronidase might supplement the dissolution process of hydrolysing the mucopolysaccharide portion of the structure. These findings, to our knowledge, represent the first identification or characterization of the enzymes effecting penetration of the zona pellucida by the spermatozoa of any species.

\section{ACKNOWLEDGMENT}

This work was supported by the Ford Foundation Grant 65-58A and the United States Public Health Service Grant 3 R01 HD-01810-03.

\section{REFERENCES}

Anson, M. L. (1938) The extinction of pepsin, trypsin, papain and cathepsin with hemoglobin. $\mathcal{J}$. gen. Physiol. 22, 79.

BEERs, R. T., JR \& Sizer, J. W. (1952) A spectrophotometric method for measuring the breakdown of hydrogen peroxide by catalase. 7. biol. Chem. 195, 133.

Bergmeyer, H. U. (1963) Methods of enzymatic analysis, p. 815. Academic Press, New York.

Bernfeld, P. (1951) Enzymes of starch degradation and synthesis. Adv. Enzymol. 12, 379.

Brandenberger, H. \& Hanson, R. (1953) Spectrophotometric determination of acid and alkaline phosphatases. Helv. chim. Acta, 36, 900.

Dickmans, Z. (1965) Sperm penetration into and through the zona pellucida of the mammalian egg. In: Preimplantation Stages of Pregnancy, p. 169, Eds. G. E. W. Wolstenholme and M. O'Connor. Churchill, London.

Fishman, W. H., Springer, B. \& BRunettr, R. (1948) Application of an improved glucuronidase assay method to the study of human blood $\beta$-glucuronidase. F. biol. Chem. 173, 449.

Fraenkel-Conrat, H., Bean, R. C., Ducay, E. D. \& Olcott, H. S. (1952) Isolation and characterization of a trypsin inhibitor from lima beans. Archs Biochem. Biophys. 37, 393.

Hummes, B. G. W. (1959) A modified spectrophotometric determination of chymotrypsin, trypsin, and thrombin. Can. F. Biochem. Physiol. 37, 1393.

Lowry, O. H., Rosebrough, N. J., FARR, A. L. \& Randall, R. J. (1951) Protein measurement with the Folin phenol reagent. F. biol. Chem. 193, 265.

MARTIN, R. S. \& AMEs, B. N. (1961) A method for determining the sedimentation behavior of enzymes: application to protein mixtures. F. biol. Chem. 236, 1372.

Mastroianni, L. \& Ehteshamzadeh, J. (1964) Corona cell dispersing properties of rabbit tubal fluid. 7. Reprod. Fert. 8, 145.

Mrtz, M. A. \& Schlueter, R. J. (1958) Direct spectrophotometric measurement of the peptide bond: application to the determination of acylase 1. Biochim. biophys. Acta, 27, 168.

Roth, J. (1959) Comparative studies on tissue ribonucleases. Ann. N.Y. Acad. Sci. 81, 611.

Shugar, D. (1952) Measurement of lysozyme activity and the ultraviolet inactivation of lysozyme. Biochim. biophys. Acta, 8, 302.

Srivastava, P. N., Adams, C. E. \& Hartree, E. F. (1965a) Enzymatic action of lipoglycoprotein preparations from sperm-acrosomes on rabbit ova. Nature, Lond. 205, 498.

SRivastava, P. N., Adams, C. E. \& Hartree, E. F. (1965b) Enzymic action of acrosomal preparations on the rabbit ovum in vitro. F. Reprod. Fert. 10,61.

Stambaugh, R. \& Buckley, J. (1967) The enzymic and molecular nature of the lactic dehydrogenase subbands and $\mathrm{X}_{4}$ isozyme. F. biol. Chem. 242, 4053.

Stambaugh, R., Noriega, C. \& Mastroianni, L. (1969) Bicarbonate ion; the corona cell dispersing factor of rabbit tubal fluid. 7. Reprod. Fert. 18, 51.

Stambaugh, R. \& Post, D. (1966) A spectrophotometric method for the assay of lactic dehydrogenase subunits. Analyt. Biochem. 15, 470.

Stambaugh, R. \& Post, D. (1967) Substrate and product inhibition of rabbit muscle lactic dehydrogenase heart $\left(\mathrm{H}_{4}\right)$ and muscle $\left(\mathbf{M}_{4}\right)$ isozymes. F. biol. Chem. 241, 1462.

Sterner, R. F. (1954) Reversible association processes of globular proteins. VI. The combination of trypsin with soybean inhibitor. Archs Biochem. Biophys. 49,71.

Tolksdorf, S., MaCready, M. H., McCullogh, D. R. \& Sichwenk, E. (1949) The turbidimetric assay of hyaluronidase. F. Lab. clin. Med. 34, 74.

Wilbur, K. M. \& ANDERSON, N. G. (1948) Electrometric and colorimetric determination of carbonic anhydrase. F. biol. Chem. 176, 147. 